\title{
Porosity in As-Cast U-Al Alloy
}

by

\author{
F. C. Rhode
}

E. I. du Pont de Nemours and Company

Savannah River Site

Aiken, South Carolina 29808

\section{RECEIVED \\ OCT 221998 \\ OSTI}

1

Y ONLY

\section{DISCLAIMER}

\begin{abstract}
This report was prepared as an account of work sponsored by an agency of the United States Government. Neither the United States Government nor any agency thereof, nor any of their empleyees, makes any warranty, express or implied, or assumes any legal liability or responsibility for the accuracy, completeness, or usefulness of any information, apparatus, product, or

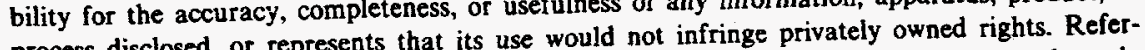
process disclosed, or represents that its use would not infringe privale brecess, or service by trade name, trademark, ence hercin to any specific does not necessarily constitute or imply its endorsement, recommanufacturer, or otherwise does United States Government or any agency thereof. The views mendation, or favoring by the United States Government or ans ate or reflect those of the and opinions of authors expressed herein do not
\end{abstract}

\section{DOE Contract No.}

This paper was prepared in connection with work done under the above contract number with the U.S.

Department of Energy. By acceptance of this paper, the publisher and/or recipient acknowledges the U. S. Government's right to retain a nonexclusive, royalty-free license in and to any copyright covering this paper, along with the right to reproduce and to authorize others to reproduce all or part of the copyrighted paper. 


\section{DISCLAIMER}

Portions of this document may be illegible in electronic image products. Images are produced from the best available original document. 


\section{INTER-OFFICE MEMORANDUM}

February 25, 1988

DPSP $88-71-3$

TO: $\quad$ J. W. RUNNELS, 704-M RAW MATERIALS DEPARTMENT

FROM: F. C. RHODE, 320-5M<smiles></smiles>

RAW MATERIALS ENGINEERING \& TECHNOLOGY DEPARTMENT

POROSITY IN AS-CAST U-AL ALLOY

\section{SUMMARY}

This memorandum documents a study that showed a cyclic occurrence of porosity in $\mathrm{U}-\mathrm{Al}$ alloys produced in Building 321-M. Review of process data shows that the extent of porosity is more pronounced in months of warm, humid weather and less pronounced in cooler, drier months, Figure 1. This porosity is most likely caused by hydrogen, which becomes dissolved in the molten U-Al alloy during casting. Although excessive porosity was the cause of some observed process anomalies, this type of porosity has no significant effect on yield or fuel tube quality.

\section{DISCUSSION}

During mid 1987 , operating personnel reported the following apparent anomalies in the U-Al casting process. Investigation showed that these were caused by variations in alloy porosity.

- Unusua11y large quantities $(>1000 \mathrm{~g})$ of excess U-AI alloy remaining in crucibles after molds were filled.

- Observation of molten alloy rising and on occasion overflowing molds as solidification proceeded.

- Atypically low ingot and machined core weights.

Hydrogen is a common cause of porosity in aluminum alloys. It becomes dissolved in molten alloy primarily by reduction of $\mathrm{H}_{2} \mathrm{O}$. The atmosphere can provide an abundant source of moisture. As a cast aluminum alloy cools and solidifies, hydrogen solubility is decreased and hydrogen gas is liberated 
J. W. Runnels

Page 2

DPSP 88-71-3

February 25,1988

as bubbles in the alloy. Some of these become trapped in the solidifled alloy and reduce its overall density. Because U-Al alloys are melted and cast in air, some porosity is always present in the as-cast structure. Typically this consists of small, uniform, isolated, spherically shaped voids. This type of porosity is normally of little consequence in the SRP fuel tube manufacturing process. Normal outgassing and extrusion steps effectively eliminate the porosity with no effect on yields or fuel tube quality.

The actual density and extent of porosity of individual U-Al ingots and machined cores is not routinely measured. However, these are produced to fairly consistent dimensions and volumes in several distinct sizes. Therefore densities should be closely proportional to weights for each size produced. During 1987, Mark 22 fuel containing about 33 wt\% U-Al was produced throughout the year. Because all sizes were not produced consistently throughout the year, trending tendencies were difficult to detect based on weights alone. Therefore a "relative density" value was determined. The average ingot and core weight for each size was determined by month. A monthly relative density of each size was determined by dividing these values by the January values. These were combined to provide a single, average relative density value for all sizes produced during each month.

Figure 1 shows the relative density of as-cast ingots and machined cores for a period of twelve (12) months and shows the cyclic occurrence. The observed anomalies coincide with the period of low relative density occurring in the late summer and early fall months. During these months, the range of apparent density in individual pieces varied by as much as $15 \%$. These large variations were discernible by operators handing the pieces. 

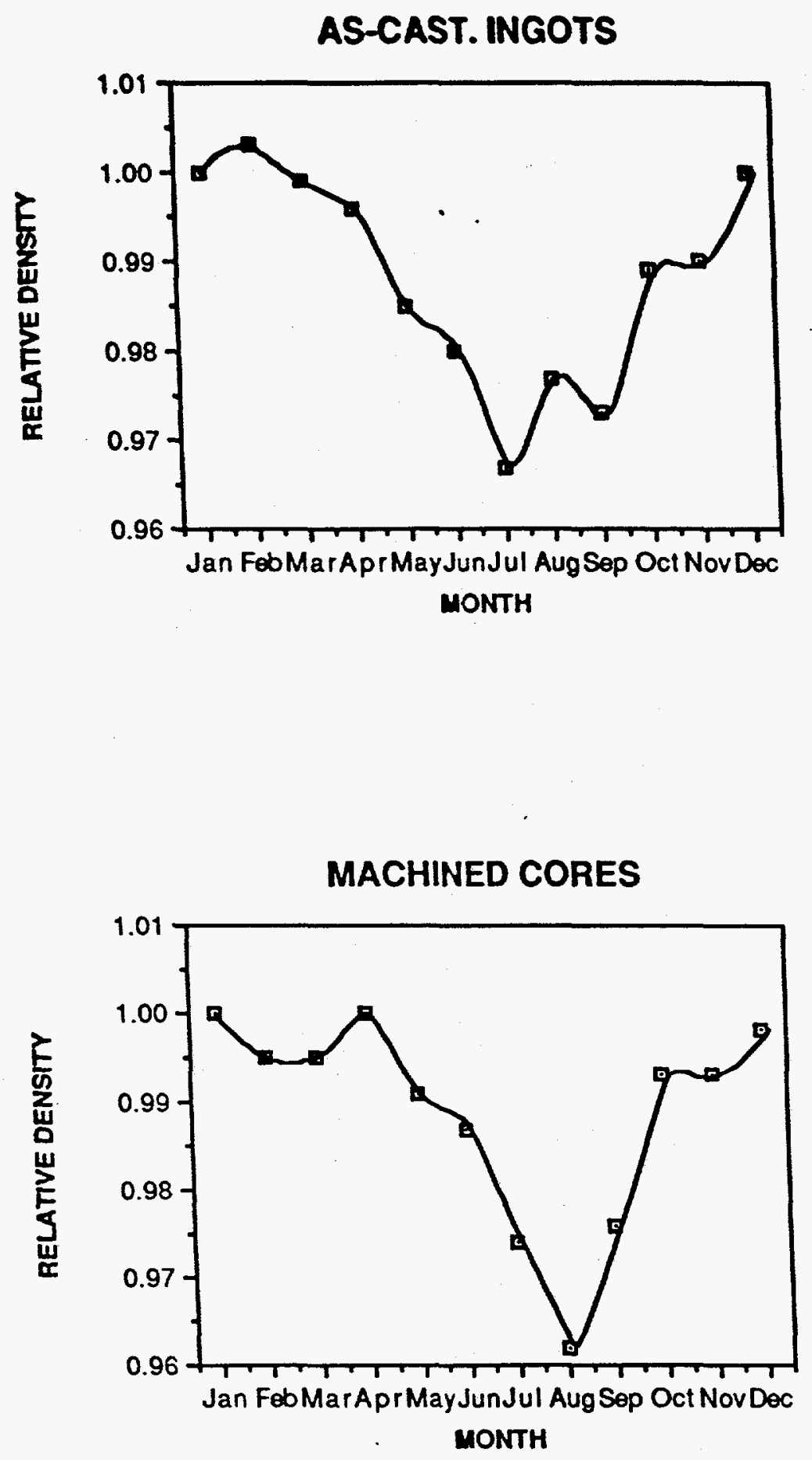

Figure 1. Relative density of as-cast U-Al Ingots and machined cores during 1987

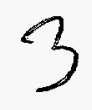

